trial power. In 1769, James Watt patented his separate condenser, which proved to be the greatest single improvement ever made in steam engines, and Richard Arkwright patented his spinning machine, which, strictly speaking, was less an invention than a successful exploitation of a much earlier machine which never quite worked. To mark the occasion, the Science Museum in London has arranged a characteristically subdued exhibition of the two original patents, borrowed from the Public Records Office, a little biographical material, a couple of florid portraits and eight or nine cases containing recent and contemporary models and drawings of Watt's work and Arkwright's original spinning machines. More interesting than the exhibition itself is a short monograph, James Watt and the Separate Condenser, by Mr R. J. Law of the museum, which was published the day the exhibition opened; it is a pity that the museum did not produce a monograph on Arkwright, who was an equally colourful character.

Watt began his work on the steam engine when he was asked to repair a model of a Newcomen engine, to be seen at the exhibition, which then belonged to the Natural Philosophy class at Glasgow University. He quickly discovered that the model would never work satisfactorily because most of the heat was used to heat the cylinder instead of moving the piston. $\mathrm{He}$ tried making a cylinder of wood soaked in linseed oil and then baked but came to the conclusion that wood was no substitute for metal and began experimenting with an engine in which the steam was condensed not in the cylinder but in a separate condenser vessel. By 1769 Watt had associated with a Scottish colliery owner called Roebuck who put up the then large sum of $£ 1,200$ for the patent of the separate condenser in exchange for a two-thirds share in it. When Roebuck went bankrupt, one of his creditors, Matthew Boulton, accepted this share in the patent as part payment of Rocbuck's debt and this led to the association of Boulton and Watt who, from their factory in Soho, Birmingham, "made engines for the world". In fact, they supplied the valves and drawings, a specially trained man to supervise erection of the engines, and specified that the cylinders must be bought from the ironfounder Wilkinson, leaving the purchaser of the engine, more often than not a Cornish copper mine owner, to build locally the beam and other simply made pieces.

Arkwright's success in making a spinning machine in 1769, when others such as Lewis Paul of Birmingham - who as early as 1738 had patented a spinning machine - had failed, stems from the exploitation of a succession of rollers to thin out the carded cotton. Paul had had the idea of using rollers in this way but his machine was too complicated for the mechanical resources of the eighteenth century. whereas Arkwright's was clegantly simple but ingenious. Once he had invented. his machine, Arkwright, who was as daring a businessman as he was an inventor, set up a factory in Nottingham and began making his fortune. To protect his monopolistic position he kept up a running fight in and out of the courts which culminated in his defeat in the courts in London in 1785 when he had the whole of the Lancashire cotton industry arguing against his plea for an extension of his patents. But in spite of all his setbacks he continued to flourish, became a landed squire in Derbyshire, lent money to the Duchess of
Devonshire to pay off her gambling debts, and rose from a poor barber to be the first cotton tycoon in Britain.

\section{RECLAMATION Waste Not, Want Not}

WHAT goes into the dustbin is more valuable than it seems. This was one of the main themes of the International Reclamation and Disposal Exhibition, held at Olympia in London from July 14 to 18 in conjunction with a conference on new ways of dealing with waste. From many of the exhibits, it was clear that much ingenuity now goes into purifying and re-using waste products that were once quietly dumped in the nearest convenient place.

The reclamation industry claims that it is already indispensable to the British economy, saving $£ 1,000$ million a year in imports. This includes the obvious example of the steel industry, where nearly 53 per cent of last year's production was based on the re-utilization of scrap. Papermakers also hope to reprocess up to two million tons of waste this year, and are actually dependent on something like this figure being reached. It is, however, in less spectacular fields that the most imaginative attempts are being made to save money by reappraising rubbish. At the Warren Spring Laboratory the recovery of metals from domestic refuse has been improved by the development of a fluidized bed separator which can sort out metals of all kinds, nonferrous as well as ferrous. Previously, while ferrous material could be removed magnetically, slow and unhygienic hand-picking methods were needed for anything else. Platinum can be recovered from discarded sparking plugs and silver from solder waste. On a larger scale, the residues from instant coffee production can be made into a wood-like plastic, so that even a literal "coffee table" is now a possibility.

Environmental pollution was not widely explored at the exhibition, which seems to have been aimed mainly at informing industry of the cconomic benefits of recovery. The more that is re-used, the less there is to be dangerous, although there is a danger that the effect of some processes is simply that noxious substances are discarded in a more concentrated form than before. A common opinion among exhibitors was that the control of pollution is basically a legal matter-manufacturers are more likely to spend money on treating what they reject if compulsion is impending. Prevention of a repetition of the recent Rhine disaster would not, it seems, be guaranteed by the normal course of research alone. It is even more difficult to know how to deal with materials such as waste plastics, which ironically are used chiefly because of their resistance to destruction. In a paper on biodegradation read to the conference on July 15, Professor D. E. Hughes of the University College of South Wales (Cardiff) argued that although biodegradable detergents are now a reality, "most of the present day polymers.... are so bioresistant that our age may be dated by future archaeologists by following the stratigraphy of specific polymers". A successful process which makes PVC fit for re-use is, unfortunately, exceptional. One solution. for recalcitrant remains might be to seal them in mineshafts as these become disused, but geological considerations 
such as interference with natural water cycles may rule out many otherwise attractive sites. The disposal of unwanted journals is made possible by devices from O. Kay Engineering Services Ltd, which has exhibited a "Newsprint Conditioner" and a "Magazine Ruffler".

\section{NATIONAL LABORATORY Oak Ridge Reshufile}

'THE Oak Ridge National Laboratory recently announced a reorganization of its Biology Division which will now operate as six sections, each with a director who will serve for a three year period. While continuing their own research, the six section leaders will help the division director, Dr H. I. Adler, and the deputy director, Dr S. F. Carson, to administer the scientific effort of the whole division.

The first six section leaders are Dr W. E. Barnett (genetics and developmental biology) who has been at Oak Ridge since 1961 working on the genetic code and its translation ; Dr F. T. Kenney (carcinogenesis) who joined the laboratory in 1959 and works on mammalian biochemistry; Dr W. L. Russell (mammalian genetics) who has been at Oak Ridge since 1947 and is working on genetics of melanin pigmentation, genetic effects of radiation, and the relative importance of heredity and the prenatal environment; $\mathrm{Dr}$ R. B. Setlow (biophysics and cell physiology) who has been the biophysicist at the laboratory since 1961 and worked on molecular biophysics, effects of ionizing and nonionizing radiation and the photochemistry of nucleic acids and proteins; a newcomer to Oak Ridge, Dr J. B. Storer, who is currently the deputy director of the AEC's Division of Biology and Medicine and who will head the pathology and immunology section; and finally the biochemistry section will be led by $\mathrm{Dr}$ E. Volkin, who has been working at Oak Ridge since 1948 on biochemistry and biophysics of nucleic acids.

\section{PLANNING}

\section{Army to the Rescue}

A solution has been found to the Tate Gallery controversy (see Nature, 221, 703; 1969) which should please everybody and which could even be ideal. Public opinion has scored, the gallery's trustees scem to be delighted, and the British Government has successfully completed what must have been tricky negotiations with the army doctors. There is even money available. The solution is that the Tate's present building with its portico and steps is almost certain to be kept intact, as an extension will be built on at the back; and the gallery will get a brand new building on the site of the Queen Alexandra's Military Hospital next door when the army doctors vacate it in about five years time. This change of plan has come about because the doctors have at last agreed to move from their Millbank site to a new military hospital which will be built on army land at Woolwich. The hospital will cost $£ 6$ million, but half of this would in any case have been spent to modernize the existing Millbank and Woolwich military hospitals.

What has obviously helped to sway the Government in the right direction was the recent decision by the
Calouste Gulbenkian Foundation to give the Tate Gallery the handsome sum of $£ 250,000$ to house temporary exhibitions. Together with the money promised by the Government-a basic contribution of $£ 850,000$ and a special contribution of $£ 200,000$ announced earlier for the Henry Moore collectionthis should go a long way towards meeting the $f 2$ million which the new proposals will cost, itself about the same as the Tate's trustees had in mind for the earlier controversial proposals. This, however, may be a little optimistic, although it is certainly a good deal less than the $£ 12$ million which the trustees last February bemoaned would be the cost of a new gallery.

Everything is not yet plain sailing. First, the design of the new building will have to be approved. Second, the Government's decision in no way clears up the thorny issue of public support for art galleries in Britain, nor the future status of the Tate itself. Will it for example, continue to be the National Gallery of British Art and the National Gallery of Modern Art under the new proposals ?

\section{CURRICULUM DEVELOPMENT Courses for Electronics}

A STEP towards closer cooperation between universities and junior colleges in the United States is made by a one-year project, based on the University of Illinois, to develop teaching materials for a new associate degree course in electronics technology. The project, directed by Professor Daniel S. Babb and supported by the National Science Foundation with a grant of $\$ 183,000$, culminates next summer in a teachers' course which will introduce the new laboratory and classroom methods and, after this, the preparation of teachers' guides should be complete in time for the new academic year. Practical testing of the ideas that emerge is to take place chiefly in Parkland Junior College (Champaign) throughout the project, though six other colleges are also concerned.

The university hopes that its work will rectify a shortage of suitably qualified teachers in the newer technological fields. It has already developed tech. niques for training, among others, microprecision technicians to work in space science, and its latest plans should help fill an equally important gap.

\section{ARCHITECTURE Prize Buildings}

A RESEARCH station and a computer centre are two of the ten buildings selected by the Royal Institute of British Architects for its awards this year. The Gas Council Engineering Research Station was selected as the best building in the northern region. It was designed by Ryder and Yates, and this is its third architectural award, having won last year's Financial Times Industrial Architecture Award and a commendation in the 1968 Civic Trust Awards. The architects were asked to design a building whose future requirements are conjectural and dependent on rescarch programmes. "The result", the jury says, "is a scheme in which there is remarkable flexibility of space and services and the skill with which this has been done is most impressive. Within the flexible framework, 